\title{
Transmission Properties of Pathogenic Protein Agents in Human Prion Disease and Neurodegenerative Diseases
}

\author{
Jared N Wilczynski and He Liu* \\ Department of Biology, Gannon University, USA
}

Submission: September 11, 2016; Published: October 07, 2016

*Corresponding author: He Liu, Department of Biology, Morosky College of Health Professions and Sciences, Gannon University, Erie, PA, USA; Email: liu017@gannon.edu

\begin{abstract}
Prion diseases are transmitted by the protein agent that can transfer its distinct misfolded structure to its normal counterparts and form insoluble aggregates in the nervous system. Recent findings led to the emergence of the prion paradigm of the protein agents that underlie neurodegenerative diseases such as Alzheimer's disease (AD) and Parkinson's disease (PD). This review will discuss current knowledge concerning both human prion diseases and prion-like transmission properties related to neurodegenerative diseases.
\end{abstract}

Keywords: Prion; Creutzfeldt-Jakob disease; neurodegenerative disease; Alzheimer's disease; Parkinson's disease

Abbreviations: AD: Alzheimer's Disease; PD: Parkinson's Disease; TSEs: Transmissible Spongiform Encephalopathies; CJD: Creutzfeldt-Jakob Disease; GALT: Gut Associated Lymphoid Tissue; BSE: Bovine Spongiform Encephalopathy; FDCs: Follicular Dendritic Cells; PRNP: PRioN Protein; LSPCs: Liposome-siRNA-Peptide Complexes

\section{Introduction}

The term prion was introduced by Prusiner [1] in 1982 "to denote a small proteinaceous infectious particle which is resistant to inactivation by most procedures that modify nucleic acids". The infectious nature of a prion is that it can be transmitted between individuals. Once in the new host, the prion acts as a template to transfer its distinct misfolded secondary structure to its normal counterparts and form insoluble aggregates in the nervous system [2,3]. Although no infectivity between individuals has been found to date in neurodegenerative diseases such as Alzheimer's disease (AD) and Parkinson's disease (PD), in particular through peripheral inoculations, these diseases exhibit prion-like characteristics in terms of propagation of abnormally folded conformation of protein agents in the same individual, then formation of protein aggregates in the nervous system. In recent years, more discoveries were made in this field and provide new insights about prion diseases and their association with other neurodegenerative diseases [4-6]. Our primary aim in this present review is to provide an overview of recent advances in the understanding of both prion diseases and prion-like transmission properties, or "prion paradigms" of $\mathrm{AD}$ and PD. Given that over 330,000 articles were found from our search by keywords on PubMed, we regret if some important findings are overlooked.

\section{Human Prion Disease}

Transmissible spongiform encephalopathies (TSEs) are a group of rare degenerative fatal brain diseases characterized by the "spongy" appearance of the tissues in the nervous system by microscopic holes as the result of apoptotic neurons surrounded by vacuoles and reactive astrocytes [7]. TSEs affect many animals, including humans, cows, goats, minks, cats, lemur, and sheep [8,9]. In humans, Creutzfeldt-Jakob Disease (CJD) is the most well-known form of TSE with different etiological subtypes.

The vast majority of CJD cases are caused by a pathogenic conformational change of the prion protein coded by the PRNP gene, [10-12] including either sporadic CJD (sCJD) which may be influenced by PRNP polymorphisms [11-13] or inherited familial CJD (fCJD), caused by an autosomal dominant germ line mutation. Some CJD cases are acquired, including iatrogenic CJD (iCJD), typically from medical treatments with prioncontamination, such as grafts of dura matter or cornea from cadavers with undiagnosed CJD. Other iCJD cases have been 
acquired through hormone treatments or blood transfusions from infected human sources [14-16].

Variant CJD (vCJD) has been a recent emergent in the European countries, which is suspected to be acquired through food contaminated with bovine prion (from mad cow disease). It exhibits similarities to Kuru, a disease among the Fore tribe of Papua New Guinea who are infected via funerary cannibalism [17-19]. The status of all types of CJD is closely monitored by the National Creutzfeldt-Jakob Disease Surveillance Unit in the United Kingdom. In 1994, the first case of VCJD was identified in the United Kingdom and it was linked to the epidemic of bovine spongiform encephalopathy (BSE) in cattle [20]. CJD affects about one in every one million people per year, worldwide [21]. Among them, most cases were sCJD, and by 2011 almost 200 cases were vCJD from the bovine origin, most of which occurred in the United Kingdom and other European countries [22].

The transmissible agent of CJD, the prion protein ( $\mathrm{PrP})$, is a membrane glycosyl phosphatidyl inositol-anchored glycoprotein encoded by the gene PRNP located on chromosome 20 [23,24]. The pathogenic PrP is designated as PrP-TSE or PrPSc (scrapie), which is converted through a posttranslational process from a normal cellular PrP, designated as PrPC (cellular or normal PrP) [3]. PrP mRNA is highly expressed in various neuro ectodermal tissues such as the brain, as well as the heart, lungs, skeletal muscles, lymphoid tissues and subsets of maturing B cells, and intestinal epithelium [24-29]. The physiological role of PrPC is not clearly defined. Some reports suggest that PrPC functions in cell signaling pathways and synaptic connections [3032]. In contrast, PrPSc has been found in the nervous system, muscle, placenta, intestines and secondary lymphoid organs [8]. In particular, PrPSc was detected in the brain tissue of all patients, while its deposition outside of the nervous system was also detected in spleen and muscle samples from about one third of patients who usually had a significantly longer duration of disease [33]. PrPSc exists in different strains which exhibit variation in physical, chemical and biological properties such as conformation, sensitivity to protease, conversion rate, aggregation, infectivity, and rate of disease progression [34-39].

Numerous studies show that the prion can be transmitted through cell culture, [40-46] cerebral inoculation, [47-57] and even peripheral inoculation [49,56,58-63]. The natural transmission pathway of a prion, in particular the pre oral infection, is currently a focus of research in order to find efficient infection control strategies against TSEs in both humans and other animals.

Substantial evidence suggests that the three key steps of prion disease transmission are through intestinal uptake, lymphoid accumulation and neuro invasion [64-67]. First, epithelial M cells (also called microfold cells) overlying the sub epithelial lymphoid follicles in the gastrointestinal tract have been recognized as a major entry site for prions $[68,69]$. These cells are specialized for antigen sampling and initiate immune responses in the gut associated lymphoid tissue (GALT), also known as Peyer's patch [70].

Prion was detected in the follicular dendritic cells (FDCs) in small intestinal GALT, but not in large intestinal GALT, before it spread to lymphoid and nervous tissues [69,71-74]. Experimental depletion of $\mathrm{M}$ cells blocked neuro invasion and disease development after oral prion exposure [75]. The absorption mechanism of prion through the $M$ cells is transcytosis, partly eased by the beta-sheet structure of PrPSc $[65,76]$. Animal experiments showed that the transcytosis of incorporating prions in the epithelial cells followed with the transport to Peyer's patches occurred within hours $[77,78]$.

The second step, lymphoid accumulation, may take several days after inoculation to spread further to mesenteric lymph nodes and the spleen, and may take several weeks to reach the peripheral nervous system [77,78]. One study showed cholesterol homeostasis, temperature, and the degradation power of macrophages are the main factors which influence the early transient accumulation of PrPSc in the first 8-12 hours post-exposure [79]. High levels of PrPC expression is found in entero endocrine and enteric nervous systems, therefore prion amplification may occur at the same time of absorption $[29,80,81]$.

The spleen is a critical site for prion accumulation. Splenectomies reduce the prion's infection efficiency [82]. Presence of peripheral PrPSc was also found in tonsillar tissue [83], the liver and the kidney[84]. The third step, neuroinvasion, is mediated by the autonomic nervous system, from the sympathetic nerves connected to the spleen and mesenteric lymph nodes to the spinal cord and eventually reaching the brain. Among the peripheral glial cells expressing PrPC, glial cells in the enteric system [85] and in the dorsal root ganglion have a permissive role in the neuroinvasion, but Schwann cells do not $[86,87]$. In the central nervous system, astrocytes and meningeal fibroblasts internalize PrPSc more efficiently than neurons and promote intercellular transfer of prion to neurons by cell-cell contact $[40,44,46]$.

Other than the GI tract, alternative entry pathways of prions have also been identified, such as transports via skeletal muscle cells and papillae in the tongue $[88,89]$, and via the olfactory nerve to the olfactory bulb through oral and nasal mucosa [9095] as lesions of the olfactory epithelium accelerated prion neuroinvasion and disease onset [96]. In addition to food, other infectious pathways, particularly in non-human animals, include mites [97], fly larvae and pupae [98], saliva (via the oral route) and blood (via transfusion) [99], gingival scarification [100], pharyngeal tonsil $[101,102]$, and skin scarification of skin or gums [103]. In human CJD patients, prion protein was detected in nasal brushings with very high sensitivity and specificity [104], suggesting this venue may need to be addressed to prevent human CJD transmission. 
To date, there is no approved treatment for TSEs. The process of clinical trials has been challenging due to the limited number of patients and ethical concerns to recruit control subjects. Therapeutic chemical drug trials in human TSEs involved antimicrobial, anti-inflammatory and analgesic substance classes [105], as well as polyanionic and polycyclic compounds with hope to prevent the conformational conversion [106]. Several novel approaches involved biological treatments. Immunotherapy tested on animal models, including immunization with vaccines and passive immunization with antibody transfers [107], showed some promising outcomes in slowing disease progression or increasing lifespan, but did not prevent the onset of the disease. One approach targets heparan sulfate which facilitates prion infection and PrPSc formation.

Over-expression of heparanase, an enzyme utilized to degrade cellular heparin sulfate, resulted in decreased levels of PrPSc within cultured cells and delayed prion disease onset and progression in infected transgenic mice [108]. Another experiment utilized the presence of heterologous proteins (hamster prion vs. murine scrapie) to inhibit the prion conformation conversion process and found reduced pathology and delayed onset of symptoms [109]. In addition, RNAi or liposome-siRNA-peptide complexes (LSPCs) have been used in experiments to knock down PrPC expression in neuro blastoma cell cultures [110-112]. Although the delivery of lentivirus encoding PrP shRNA has been a limiting factor in efficacy in vivo, the recent development of lipid nanoparticle (LNP) may provide a more efficient delivery method of siRNA across the blood-brain barrier [113].

\subsection{Prion association of neurodegenerative diseases}

Several neurodegenerative diseases share similar pathological characteristics of abnormal folding of protein agents. Most of the research efforts have been focused on proteins amyloid-beta $(A \beta)$, tau, and $\alpha$-synuclein ( $\alpha$-syn), since these proteins correspond to AD and PD, the two most prevalent neurodegenerative diseases in elders. In recent years, the prion paradigms of these proteins emerged as these protein agents show cell-cell transmissibility like prion PrP in many research studies.

$\mathrm{AD}$ is the most prevalent cause of dementia [114]. The hallmark characteristic of $\mathrm{AD}$ pathology is the plaque aggregation of abnormally folded amyloid-beta $(A \beta)$ proteins in the extracellular space and intracellular fibrillary tangles of phosphorylated tau protein. The major risk factors of AD include age, apolipoprotein E $\varepsilon 4$ (APOE) gene (over $60 \%$ of AD patients have at least one allele) and sex (60\% of AD patients are female) $[115,116]$.

Plaques are formed by $A \beta$ 1-40/1-42 peptides, cleaved by $\beta$ - and $\gamma$-secretases. The progression of $A D$ implies that $A \beta$ may propagate its abnormal folding in the brain. $A \beta$ deposition was identified to spread in the brain in 5 phases: the neocortex (phase 1), allocortical regions (phase 2), diencephalon nuclei, striatum, and the cholinergic nuclei of the basal forebrain (phase 3 ), brain stem nuclei (phase 4), and eventually the cerebellum (phase 5) [117]. Cumulative evidence suggests synapse failure and neural dysfunction in $\mathrm{AD}$ is due to the toxicity which impairs neurons that start with small diffusible $A \beta$ oligomers before the formation of plaque [118-122]. It is worthy to note a recent report challenges this hypothesis by showing that $A \beta 42$ immunization cleared amyloid plaques but failed to prevent the progression of neurodegeneration [123].

The oligomer cascade hypothesis states that the $A \beta$ oligomers are accumulated intracellularly in the small cytoplasmic granules located within neurites and synapses $[119,124,125]$, and then secreted from the neurons [126]. The secretion and spread of $A \beta$ oligomers pathology led to speculation of its prion-like propagation, which is supported by experiments with cell cultures [126-131]. Many studies also show that only intracerebral inoculation, but not oral, intravenous, intraocular, or intranasal ways induced cerebral $\beta$-amyloidosis in animal models [132-140], specifically in rat [141] as well as in primates [142].

In 2015, several reports showed intriguing links between $\mathrm{AD}$ and CJD in CJD patients. Two reports showed the majority of patients with iCJD who received prion-contaminated c-hGH treatments exhibited various levels of $\mathrm{A} \beta$ deposits in the gray matter of the brain, as well as in the blood vessel walls $[4,5]$, increasing the possibility that the $A \beta$ might be transmitted from a peripheral route. However, another report showed $17 \%$ of 266 prion disease cases (mostly sCJD) showed concurrent extracellular $\mathrm{A} \beta$ plaques. [6] The majority of these concurrent plaques were seen in SCJD patients (42 cases).

These cases suggest that PrPSc and A $\beta$ may have some intrinsic association even though it is not passed between individuals. Putative explanations are that PrPC may act as a high-affinity receptor of $A \beta$, or it regulates the cleavage of the amyloid precursor protein through $\beta$-secretase $[143,144]$. These alternative hypotheses are not exclusive as the frequency of $A \beta$ seen in these iCJD cases (50\%) is significantly higher than the frequency in age-matched SCJD cases $(10 \%$ and $17 \%$ in two reports) [5,6,145].

The appearance of intracellular fibrillary tangles formed by phosphorylated tau proteins is another defining feature of $\mathrm{AD}$, and is seen in other neurodegenerative disorders [146148]. Buildup of $A \beta$ over decades can trigger tau aggregation $[149,150]$. Although not as many studies on $A \beta$, some studies have shown that tau can be transmitted from human patient brain homogenates or synthetic tau fibrils, to cell culture or transgenic mice expressing human tau protein [151-162].

Three main types of diseases are categorized as $\alpha$-synucleinopathies: PD, dementia with Lewy bodies (DLB), [163-165] and multiple system atrophy (MSA) [166-168]. 
These are neurodegenerative diseases which share common pathological hallmarks of deposition of intracellular $\alpha$-syn aggregates within inclusions (Lewy bodies and Lewy neurites) in neurons and glia [169]. Among the diseases, PD is the most common movement disorder, prevalent in $1 \%$ of the world population over age 60 [170,171].

The known risk factors of PD include mutations in several genes, such as SNCA, LRRK2, and GBA, and environmental toxins such as pesticides [172]. In DLB patients, Lewy body-related pathology is distributed from the brain stem to the cerebral cortex and is often associated with concurrent Alzheimer's disease pathology [163-165]. MSA is a neurodegenerative disorder characterized by a combination of autonomic dysfunction, cerebellar ataxia and Parkinsonism [166-168].

The protein underlying these diseases is $\alpha$-syn, a protein that is soluble in its monomer and oligomer forms, but becomes insoluble when the oligomer undergoes fibrillation within neurons and glia [173]. The pathology of PD can spread through the brain, with 6 stages proposed by Braak [174]: the medulla oblongata/pontine tegmentum and olfactory bulb/anterior olfactory nucleus in presymptomatic (stages 1-2), the substantia nigra and other nuclear grays of the midbrain and forebrain in symptomatic (stages 3-4), and the mature neocortex in the end (stages 5-6).

The propagating pathology suggests the prion-like property of $\alpha$-syn in the brain, which is supported by clinical reports and animal experiments. Two independent clinical reports showed that grafted healthy neurons gradually developed the same pathology of Lewy bodies containing $\alpha$-syn aggregates 11-16 years after transplantation, in three recipients with pre-existing PD $[175,176]$. Prion-like propagation of $\alpha$-syn was also observed in many experiments with cell cultures [177-185] and animal experiments [179,183,186-197].

The spread of disease may be initiated from a peripheral site shown by an intramuscular injection in mice [198]. The proposed model of intracellular $\alpha$-syn transfer involves an exocytotic secretion and entry of the recipient cell through simple diffusion or lipid raft-mediated endocytosis [199,200]. Growing evidence showed monomeric and oligomeric, but not fibrillary form of $\alpha$-syn can propagate along neural pathways [176,201-203]. A recent report in 2016 suggests that $\alpha$-syn exists in a "continuum" of species with various numbers of monomers and molecular weights. Mature $\alpha$-syn fibrils and stable elongated oligomers composed of more than $15 \alpha$-syn monomers have seeding capacity, while low-molecular weight and unstable oligomers do not [204]. Another report in 2016 showed very high numbers of seeds and cellular stress which are two necessary conditions for seeding [205]. Synergistic effects between $\alpha$-syn and tau to promote fibrillation of both proteins have been observed in multiple studies [206,207]. Tau shifted the pattern of $\alpha$-syn aggregation and increased the toxicity of $\alpha$-syn [208].

\section{Conclusion}

To date, prion PrP is the only protein agent that was found to transmit diseases between individuals by acting as a template to transfer its misfolding to its normal counterparts and form insoluble aggregates in the nervous system. However, with a growing body of evidence, the recently emerging "prion paradigm" connects the pathological hallmarks of common neurodegenerative diseases with the transmission property of prion protein.

If $A \beta$, tau, or $\alpha$-syn may be transmitted through peripheral pathways in clinical settings, many clinical procedures will need to be re-examined when human proteins are transferred between individuals such as blood transfusion, or even the clinical sterilization methods as they resist formaldehyde or a commonly used disinfectant per acetic acid. [209,210] Many reports (recent examples in the last three years are summarized in Table 1), with cell culture and transfusion, support the association which may provide the basis of further understanding of the pathologies and therapeutic developments of these diseases.

Table 1: Propagation of Proteins in Experimental Systems.

\begin{tabular}{|c|c|c|}
\hline Protein Agent & Transmission Method & Reports \\
\hline \multirow{4}{*}{ Prion } & Cell Culture & Multiple reports [41-46] \\
\cline { 2 - 3 } & Cerebral & $\begin{array}{c}\text { Multiple reports [47- } \\
\text { 57,211] }\end{array}$ \\
\cline { 2 - 3 } & Peripheral & $\begin{array}{c}\text { Multiple reports } \\
{[49,56,58-63]}\end{array}$ \\
\hline \multirow{4}{*}{ A-beta } & Cell Culture & $\begin{array}{c}\text { Multiple reports [127- } \\
131]\end{array}$ \\
\cline { 2 - 3 } & Cerebral & $\begin{array}{c}\text { Multiple reports } \\
{[131,139,140]}\end{array}$ \\
\cline { 2 - 3 } & Peripheral & $\begin{array}{c}\text { Two reports in iCJD } \\
\text { patients [4,5] }\end{array}$ \\
\hline \multirow{7}{*}{ Tau } & Cell Culture & $\begin{array}{c}\text { Multiple reports } \\
{[152,159-161]}\end{array}$ \\
\cline { 2 - 3 } & Cerebral & $\begin{array}{c}\text { Multiple reports [155- } \\
158,160,161]\end{array}$ \\
\cline { 2 - 3 } & Peripheral & N/A \\
\cline { 2 - 3 } & Cell Culture & $\begin{array}{c}\text { Multiple reports [180- } \\
185]\end{array}$ \\
\hline \multirow{7}{*}{ alpha-syn } & Cerebral & $\begin{array}{c}\text { Multiple reports } \\
{[183,190,192-195,197]}\end{array}$ \\
\cline { 2 - 3 } & Peripheral & $\begin{array}{c}\text { Intramuscular injection } \\
\text { in mice [198] }\end{array}$ \\
\cline { 2 - 3 } & & \\
\cline { 2 - 3 } & &
\end{tabular}

\section{Conflict of Interest: None}

\section{References}

1. Prusiner SB (1982) Novel proteinaceous infectious particles cause scrapie. Science 216(4542): 136-144.

2. Bessen RA, Kocisko DA, Raymond GJ, Nandan S, Lansbury PT, et al. (1995) Non-genetic propagation of strain-specific properties of scrapie prion protein. Nature 375(6533): 698-700.

3. Prusiner SB (1998) Prions. Proc Natl Acad Sci U S A 95(23): 1336313383. 
4. Jaunmuktane Z, Mead S, Ellis M, Jonathan D F Wadsworth, Andrew Nicoll, et al. (2015) Evidence for human transmission of amyloid-beta pathology and cerebral amyloid angiopathy. Nature 525(7568): $247-$ 250 .

5. Frontzek K, Lutz MI, Aguzzi A, Kovacs GG, Budka H (2016) Amyloidbeta pathology and cerebral amyloid angiopathy are frequent in iatrogenic Creutzfeldt-Jakob disease after dural grafting. Swiss medical wkly 146: w14287.

6. Tousseyn T, Bajsarowicz K, Sanchez H, Gheyara A, Oehler A et al. (2015) Prion Disease Induces Alzheimer Disease-Like Neuropathologic Changes. J Neuropathol Exp Neurol 74(9): 873-888.

7. Scallet AC, Ye X (1997) Excitotoxic mechanisms of neurodegeneration in transmissible spongiform encephalopathies. Ann N Y Acad Sci 825 : 194-205.

8. Imran M, Mahmood S (2011) An overview of animal prion diseases. Virol J 8: 493.

9. Greenlee JJ, Greenlee MH (2015) The transmissible spongiform encephalopathies of livestock. ILAR J 56(1): 7-25.

10. Will RG, Alperovitch A, Poser S, Pocchiari M, Hofman A, et al. (1998) Descriptive epidemiology of Creutzfeldt-Jakob disease in six European countries, 1993-1995. EU Collaborative Study Group for CJD. Ann Neurol 43(6): 763-767.

11. Jeong BH, Kim YS (2014) Genetic studies in human prion diseases. J Korean Med Sci 29(5): 623-632.

12. Kobayashi A, Teruya K, Matsuura Y, Shirai T, Nakamura Y, et al. (2015) The influence of PRNP polymorphisms on human prion disease susceptibility: an update. Acta Neuropathol 130(2): 159-170.

13. Gambetti P, Kong Q, Zou W, Parchi P, Chen SG (2003) Sporadic and familial CJD: classification and characterisation. Br Med Bull 66: 213239.

14. Brown P, Gajdusek DC, Gibbs CJ Jr, Asher DM (1985) Potential epidemic of Creutzfeldt-Jakob disease from human growth hormone therapy. N Engl J Med 313(12): 728-731.

15. Swerdlow AJ, Higgins CD, Adlard P, Jones ME, Preece MA (2003) Creutzfeldt-Jakob disease in United Kingdom patients treated with human pituitary growth hormone. Neurology 61(6):783-791.

16. Brown P, Brandel JP, Sato T, Yosikazu Nakamura, Jan MacKenzie, et al. (2012) Iatrogenic Creutzfeldt-Jakob disease, final assessment. Emerg Infect Dis 18(6): 901-907.

17. Lee HS, Brown P, Cervenakova L, Garruto RM, Alpers MP, et al. (2001) Increased susceptibility to Kuru of carriers of the PRNP 129 methionine/methionine genotype. J Infect Dis 183(2):192-196.

18. McLean CA (2008) The neuropathology of kuru and variant CreutzfeldtJakob disease. Philos Trans R Soc Lond B Biol Sci 363(1510): 36853687 .

19. Liberski PP (2013) Kuru: a journey back in time from papua new Guinea to the neanderthals' extinction. Pathogens 2(3): 472-505.

20. Will RG, Ironside JW, Zeidler M, Estibeiro K, Cousens SN, et al. (1996) A new variant of Creutzfeldt-Jakob disease in the UK. Lancet 47(9006): 921-925.

21. NIN (2016) What is Creutzfeldt-Jakob Disease. NIN, USA.

22. WHO (2012) Variant Creutzfeldt-Jakob disease. WHO, Geneva Switzerland.

23. Liao YC, Lebo RV, Clawson GA, Smuckler EA (1986) Human prion protein cDNA: molecular cloning, chromosomal mapping, and biological implications. Science 233(4761): 364-367.
24. Kretzschmar HA, Stowring LE, Westaway D, Stubblebine WH, Prusiner SB, et al. (1986) Molecular cloning of a human prion protein cDNA. DNA 5(4): 315-324.

25. Brown HR, Goller NL, Rudelli RD, Merz GS, Wolfe GC, et al. (1990) The mRNA encoding the scrapie agent protein is present in a variety of non-neuronal cells. Acta neuropathol 80(1): 1-6.

26. Liu T, Li R, Wong BS, Liu D, Pan T, et al. (2001) Normal cellular prion protein is preferentially expressed on subpopulations of murine hemopoietic cells. J Immunol 166(6): 3733-3742.

27. Morel E, Fouquet S, Chateau D, Yvernault L, Frobert Y, et al. (2004) The cellular prion protein PrPc is expressed in human enterocytes in cellcell junctional domains. J Biol Chem 279(2): 1499-1505.

28. Paltrinieri S, Comazzi S, Spagnolo V, Rondena M, Ponti W, et al. (2004) Bovine Doppel (Dpl) and prion protein (PrP) expression on lymphoid tissue and circulating leukocytes. J Histochem Cytochem 52(12): 16391645.

29. Ford MJ, Burton LJ, Morris RJ, Hall SM (2002) Selective expression of prion protein in peripheral tissues of the adult mouse. Neuroscience 113(1): 177-192.

30. Linden R, Martins VR, Prado MA, Cammarota M, Izquierdo I, et al. (2008) Physiology of the prion protein. Physiol Rev 88(2): 673-728.

31. Didonna A (2013) Prion protein and its role in signal transduction. Cell Mol Biol Lett 18(2):209-230.

32. Hirsch TZ, Hernandez Rapp J, Martin Lanneree S, Launay JM, et al. (2014) PrP(C) signalling in neurons: from basics to clinical challenges. Biochimie 104: 2-11.

33. Glatzel M, Abela E, Maissen M, Aguzzi A (2003) Extraneural pathologic prion protein in sporadic Creutzfeldt-Jakob disease. N Engl J Med 349(19): 1812-1820.

34. Silveira JR, Raymond GJ, Hughson AG, Richard E Race, Valerie L Sim, et al. (2005) The most infectious prion protein particles. Nature 437(7056): 257-261.

35. Tixador P, Herzog L, Reine F, Jaumain E, Chapuis J, et al. (2010) The physical relationship between infectivity and prion protein aggregates is strain-dependent. PLoS pathog 6(4): e1000859.

36. Kim C, Haldiman T, Cohen Y, Chen W, Blevins J, et al. (2011) Proteasesensitive conformers in broad spectrum of distinct PrPSc structures in sporadic Creutzfeldt-Jakob disease are indicator of progression rate. PLoS pathog 7(9): e1002242.

37. Bett C, Joshi-Barr S, Lucero M, Trejo M, Liberski P, et al. (2012) Biochemical properties of highly neuroinvasive prion strains. PLoS Pathog 8(2): e1002522.

38. Kim C, Haldiman T, Surewicz K, Cohen Y, Chen W, et al. (2012) Small protease sensitive oligomers of PrPSc in distinct human prions determine conversion rate of PrP(C). PLoS Pathog 8(8): e1002835.

39. Laferriere F, Tixador P, Moudjou M, Chapuis J, Sibille P, et al. (2013) Quaternary structure of pathological prion protein as a determining factor of strain-specific prion replication dynamics. PLoS Pathog 9(10): e1003702.

40. Cronier S, Laude H, Peyrin JM (2004) Prions can infect primary cultured neurons and astrocytes and promote neuronal cell death. Proc Natl Acad Sci U S A 101(33): 12271-12276.

41. Iwamaru Y, Takenouchi T, Imamura M, Shimizu Y, Miyazawa K, et al. (2013) Prion replication elicits cytopathic changes in differentiated neurosphere cultures. J Virol 87(15): 8745-8755.

42. Chen C, Lv Y, Zhang BY, Zhang J, Shi Q, et al. (2014) Apparent reduction of ADAM10 in scrapie-infected cultured cells and in the brains of scrapie-infected rodents. Mol Neurobiol 50(3): 875-887. 


\section{International Journal of Cell Science \& Molecular Biology}

43. Oelschlegel AM, Geissen M, Lenk M, Riebe R, Angermann M, et al. (2015) A bovine cell line that can be infected by natural sheep scrapie prions. PloS One 10(1): e0117154.

44. Hollister JR, Lee KS, Dorward DW, Baron GS (2015) Efficient uptake and dissemination of scrapie prion protein by astrocytes and fibroblasts from adult hamster brain. PloS One 10(1): e0115351.

45. Xiao K, Zhang BY, Zhang XM, Wang J, Chen C, et al. (2016) Re-infection of the prion from the scrapieinfected cell line SMB-S15 in three strains of mice, CD1, C57BL/6 and Balb/c. Int J Mol Med 37(3): 716-726.

46. Victoria GS, Arkhipenko A, Zhu S, Syan S, Zurzolo C (2016) Astrocyteto-neuron intercellular prion transfer is mediated by cell-cell contact. Sci Rep 6: 20762.

47. Bishop MT, Diack AB, Ritchie DL, Ironside JW, Will RG, et al. (2013) Prion infectivity in the spleen of a PRNP heterozygous individual with subclinical variant Creutzfeldt-Jakob disease. Brain 136(Pt 4): 11391145 .

48. Takeuchi A, Kobayashi A, Ironside JW, Mohri S, Kitamoto T (2013) Characterization of variant Creutzfeldt-Jakob disease prions in prion protein-humanized mice carrying distinct codon 129 genotypes. J Biol Chem 288(30): 21659-21666.

49. Vickery CM, Beck KE, Simmons MM, Hawkins SA, Spiropoulos J (2013) Disease characteristics of bovine spongiform encephalopathy following inoculation into mice via three different routes. Int J Exp Pathol 94(5): 320-328.

50. Torres JM, Castilla J, Pintado B, Gutiérrez-Adan A, Andréoletti O, et al. (2013) Spontaneous generation of infectious prion disease in transgenic mice. Emerg Infect Dis 19(12): 1938-1947.

51. Rangel A, Race B, Phillips K, Striebel J, Kurtz N, et al. Distinct patterns of spread of prion infection in brains of mice expressing anchorless or anchored forms of prion protein. Acta Neuropathol Commun 2: 8.

52. Jeffrey M, Martin S, Chianini F, Eaton S, Dagleish MP, et al. (2014) Incidence of infection in Prnp ARR/ARR sheep following experimental inoculation with or natural exposure to classical scrapie. PloS One 9(3): e91026.

53. Halliez S, Reine F, Herzog L, Jaumain E, Haïk S, et al. (2014) Accelerated, spleen-based titration of variant Creutzfeldt-Jakob disease infectivity in transgenic mice expressing human prion protein with sensitivity comparable to that of survival time bioassay. J Virol 88(15): 86788686.

54. Greenlee JJ, Kunkle RA, Richt JA, Nicholson EM, Hamir AN (2014) Lack of prion accumulation in lymphoid tissues of PRNP ARQ/ARR sheep intracranially inoculated with the agent of scrapie. PloS One 9(9): e108029.

55. Wang J, Zhang J, Shi Q, Zhang BY, Chen C, et al. (2015) Scrapie infection in experimental rodents and SMB-S15 cells decreased the brain endogenous levels and activities of Sirt1. J Mol Neurosci 55(4): 1022 1030.

56. Simmons MM, Moore SJ, Lockey R, Chaplin MJ, Konold T, et al (2015) Phenotype shift from atypical scrapie to CH1641 following experimental transmission in sheep. PloS One 10(2): e0117063.

57. Chesebro B, Striebel J, Rangel A, Katie Phillips, Andrew Hughson, et al (2015)_Early Generation of New PrPSc on Blood Vessels after Brain Microinjection of Scrapie in Mice. mBio 6(5): e01419-e01415.

58. Nichols TA, Spraker TR, Rigg TD, Crystal Meyerett-Reid, Clare Hoover et al. (2013) Intranasal inoculation of white-tailed deer (Odocoileus virginianus) with lyophilized chronic wasting disease prion particulate complexed to montmorillonite clay. PloS one 8(5): e62455.

59. Gonzalez L, Pitarch JL, Martin S, Thurston L, Simmons H, et al. (2014) Influence of polymorphisms in the prion protein gene on the pathogenesis and neuropathological phenotype of sheep scrapie after oral infection. J Comp Pathol 150(1): 57-70.

60. Spiropoulos J, Hawkins SA, Simmons MM, Bellworthy SJ (2014) Evidence of in utero transmission of classical scrapie in sheep. J virol 88(8): 4591-4594.

61. Wang X, McGovern G, Zhang Y, Wang F, Zha L, et al. (2015) Intraperitoneal Infection of Wild-Type Mice with Synthetically Generated Mammalian Prion. PLoS Pathog 11(7): e1004958.

62. Gossner AG, Hopkins J (2015) The effect of PrP(Sc) accumulation on inflammatory gene expression within sheep peripheral lymphoid tissue. Vet Microbiol 181(3-4): 204-211.

63. Greenlee JJ, Smith JD, Hamir AN (2016) Oral inoculation of neonatal Suffolk sheep with the agent of classical scrapie results in $\operatorname{PrP}(\mathrm{Sc})$ accumulation in sheep with the PRNP ARQ/ARQ but not the ARQ/ARR genotype. Res vet sci Apr 105: 188-191.

64. Davies GA, Bryant AR, Reynolds JD, Jirik FR, Sharkey K (2006) Prion diseases and the gastrointestinal tract. Can J Gastroenterol 20(1):1824.

65. Mabbott NA, MacPherson GG (2006) Prions and their lethal journey to the brain. Nat rev biol 4(3): 201-211.

66. Beekes M, McBride PA (2007) The spread of prions through the body in naturally acquired transmissible spongiform encephalopathies. FEBS ] 274(3):588-605.

67. O'Connor T, Aguzzi A (2013) Prions and lymphoid organs: solved and remaining mysteries. Prion 7(2):157-163.

68. Colizzo F, Krantz MJ, Fish JE, Hastie AT (1992) Ciliated respiratory epithelial surface changes after formaldehyde exposure. J Toxicol Environ Health 35(4): 221-234.

69. Donaldson DS, Else KJ, Mabbott NA (2015) The Gut-Associated Lymphoid Tissues in the Small Intestine, Not the Large Intestine, Play a Major Role in Oral Prion Disease Pathogenesis. J Virol 89(18): 95329547.

70. Wolf JL, Bye WA (1984) The membranous epithelial (M) cell and the mucosal immune system. Annu Rev Med 35: 95-112.

71. Mabbott NA, Bruce ME (2002) Follicular dendritic cells as targets for intervention in transmissible spongiform encephalopathies. Semin immunol 14(4): 285-293.

72. Heggebo R, Gonzalez L, Press CM, Gunnes G, Espenes A, et al. (2003) Disease-associated $\mathrm{PrP}$ in the enteric nervous system of scrapieaffected Suffolk sheep. J Gen Virol 84(Pt 5):1327-1338.

73. Glaysher BR, Mabbott NA (2007) Role of the GALT in scrapie agent neuroinvasion from the intestine. J Immunol 178(6): 3757-3766.

74. Mabbott NA, Bradford BM (2015) The Good, the Bad, and the Ugly of Dendritic Cells during Prion Disease. J Immunology Res 2015: 168574.

75. Donaldson DS, Kobayashi A, Ohno H, Yagita H, Williams IR, et al. (2012) $\mathrm{M}$ cell-depletion blocks oral prion disease pathogenesis. Mucosal Immunol 5(2):216-225.

76. Miyazawa K, Kanaya T, Takakura I, Tanaka S, Hondo T, et al. (2010) Transcytosis of murine-adapted bovine spongiform encephalopathy agents in an in vitro bovine M cell model. J Virol 84(23): 12285-12291.

77. Takakura I, Miyazawa K, Kanaya T, Itani W, Watanabe K, et al. (2011) Orally administered prion protein is incorporated by $\mathrm{m}$ cells and spreads into lymphoid tissues with macrophages in prion protein knockout mice. Am J Pathol 179(3): 1301-1309.

78. Kujala P, Raymond CR, Romeijn M, et al. (2011) Prion uptake in the gut: identification of the first uptake and replication sites. PLoS pathog 7(12): e1002449. 
79. Elhelaly AE, Inoshima Y, Ishiguro N (2013) Characterization of early transient accumulation of $\operatorname{PrP}(\mathrm{Sc})$ in immune cells. Biochem Biophys Res Commun 439(3): 340-345.

80. Marcos Z, Pffeifer K, Bodegas ME, Sesma MP, Guembe L (2004) Cellular prion protein is expressed in a subset of neuroendocrine cells of the rat gastrointestinal tract. J Histochem Cytochem 52(10): 1357-1365.

81. Albanese V, Lawson VA, Hill AF, Cappai R, Di Guardo G, et al. (2008) Evidence for prion protein expression in enteroglial cells of the myenteric plexus of mouse intestine. Auton Neurosci 140(1-2): 17-23.

82. Kimberlin RH, Walker CA (1989) The role of the spleen in the neuroinvasion of scrapie in mice. Virus Res 12(3):201-211.

83. Hilton DA, Fathers E, Edwards P, Ironside JW, Zajicek J (1998) Prion immunoreactivity in appendix before clinical onset of variant Creutzfeldt-Jakob disease. Lancet 352(9129):703-704.

84. Urayama A, Morales R, Niehoff ML, Banks WA, Soto C (2011) Initial fate of prions upon peripheral infection: half-life, distribution, clearance, and tissue uptake. FASEB J 25(8): 2792-2803.

85. Seelig DM, Mason GL, Telling GC, Hoover EA (2011) Chronic wasting disease prion trafficking via the autonomic nervous system. Am J Pathol 179(3): 1319-1328.

86. Follet J, Lemaire-Vieille C, Blanquet-Grossard F, Podevin-Dimster V Lehmann S, et al. (2002) PrP expression and replication by Schwann cells: implications in prion spreading. J Virol 76(5): 2434-2439.

87. Bradford BM, Tuzi NL, Feltri ML, McCorquodale C, Cancellotti E, et al. (2009) Dramatic reduction of PrP C level and glycosylation in peripheral nerves following PrP knock-out from Schwann cells does not prevent transmissible spongiform encephalopathy neuroinvasion. J Neurosci 29(49):15445-15454.

88. Mulcahy ER, Bartz JC, Kincaid AE, Bessen RA (2004) Prion infection of skeletal muscle cells and papillae in the tongue. J Virol 78(13): 67926798.

89. Trifilo MJ, Ying G, Teng C, Oldstone MB (2007) Chronic wasting disease of deer and elk in transgenic mice: oral transmission and pathobiology. Virology 365(1): 136-143.

90. DeJoia C, Moreaux B, O’Connell K, Bessen RA (2006) Prion infection of oral and nasal mucosa. J Virol. 80(9): 4546-4556.

91. Corona C, Porcario C, Martucci F, Iulini B, Manea B, et al. (2009) Olfactory system involvement in natural scrapie disease. Journal of virology83(8): 3657-3667.

92. Bessen RA, Shearin H, Martinka S, Boharski R, Lowe D, et al. (2010) Prion shedding from olfactory neurons into nasal secretions. PLoS pathog 6(4): e1000837.

93. Bessen RA, Wilham JM, Lowe D, Watschke CP, Shearin H, et al. (2012) Accelerated shedding of prions following damage to the olfactory epithelium. J virol 86(3): 1777-1788.

94. Tamguney G, Richt JA, Hamir AN, Greenlee JJ, Miller MW et al. (2012) Salivary prions in sheep and deer. Prion 6(1): 52-61.

95. Clouse MD, Shikiya RA, Bartz JC, Kincaid AE (2015) Nasal associated lymphoid tissue of the Syrian golden hamster expresses high levels of PrPC. PloS one 10(2): e0117935.

96. Crowell J, Wiley JA, Bessen RA (2015) Lesion of the olfactory epithelium accelerates prion neuroinvasion and disease onset when prion replication is restricted to neurons. PloS one 10(3): e0119863.

97. Wisniewski HM, Sigurdarson S, Rubenstein R, Kascsak RJ, Carp RI (1996) Mites as vectors for scrapie. 347(9008):1114.

98. Post K, Riesner D, Walldorf V, Mehlhorn H (1999) Fly larvae and pupae as vectors for scrapie. Lancet 354(9194):1969-1970.
99. Mathiason CK, Powers JG, Dahmes SJ, Osborn DA, Miller KV, et al. (2006) Infectious prions in the saliva and blood of deer with chronic wasting disease. Science 314(5796): 133-136.

100. Carp RI (1982). Transmission of scrapie by oral route: effect of gingival scarification. Lancet 1(8264):170-171.

101. Toppets V, Piret J, Kirschvink N, Lantier F, Lantier I, et al. Neuroimmune connections in ovine pharyngeal tonsil: potential site for prion neuroinvasion. Cell Tissue Res 348(1):167-176.

102. Cancedda MG, Di Guardo G, Chiocchetti R, Demontis F, Marruchella $\mathrm{G}$, et al. Role of palatine tonsils as a prion entry site in classical and atypical experimental sheep scrapie. J virol 88(2):1065-1070.

103. Taylor DM, McConnell I, Fraser H (1996) Scrapie infection can be established readily through skin scarification in immunocompetent but not immunodeficient mice. J Gen virol 77 ( Pt 7):1595-1599.

104. Orru CD, Bongianni M, Tonoli G, Sergio Ferrari, Andrew G Hughson, et al. (2014) A test for Creutzfeldt-Jakob disease using nasal brushings. The New England journal of medicine 371(6): 519-529.

105.Zerr I (2009) Therapeutic trials in human transmissible spongiform encephalo-pathies: recent advances and problems to address. Infectious disorders drug targets 9(1): 92-99.

106. Panegyres PK, Armari E (2013) Therapies for human prion diseases. Am J Neurodegener Dis 2(3): 176-186.

107. Roettger Y, Du Y, Bacher M, Zerr I, Dodel R, et al.(2013)Immunotherapy in prion disease. Nat Rev Neurol 9(2): 98-105.

108. Kovalchuk Ben-Zaken O, Nissan I, Tzaban S, Taraboulos A, Zcharia E et al. (2015) Transgenic over-expression of mammalian heparanase delays prion disease onset and progression. Biochem Biophys Res Commun 464(3): 698-704.

109. Skinner PJ, Kim HO, Bryant D, Kinzel NJ, Reilly C, et al. (2015) Treatment of Prion Disease with Heterologous Prion Proteins. PloS one 10(7): e0131993.

110. Daude N, Marella M, Chabry J (2003) Specific inhibition of pathological prion protein accumulation by small interfering RNAs. Journal of cell science 116(Pt 13): 2775-2779.

111.Schettini F, de Mattia D, Mautone A, Altomare M (1976) Post-natal development of factor II (pre-prothrombin and prothrombin) in man. Biol Neonate 29(1-2): 82-88.

112. Kim Y, Han B, Titlow W, Mays CE, Kwon M, Ryou C (2009) Utility of RNAi-mediated prnp gene silencing in neuroblastoma cells permanently infected by prions: potentials and limitations. Antiviral Res 84(2): 185-193.

113. Bruun J, Larsen TB, Jolck RI, Eliasen R, Holm R, et al. (2015) Investigation of enzyme-sensitive lipid nanoparticles for delivery of siRNA to blood-brain barrier and glioma cells. Int J Nanomedicine 10: 5995-6008.

114. Prince M, Bryce R, Albanese E, Wimo A, Ribeiro W, et al. (2013) The global prevalence of dementia: a systematic review and metaanalysis. Alzheimer's \& dementia : the journal of the Alzheimer's Association. 9(1): 63-75.

115. Kanekiyo T, Xu H, Bu G (2014) ApoE and Abeta in Alzheimer's disease: accidental encounters or partners? Neuron 81(4):740-754.

116. Riedel BC, Thompson PM, Brinton RD (2016) Age, APOE and sex: Triad of risk of Alzheimer's disease. J Steroid Biochem Mol Biol 160:134-147.

117. Thal DR, Rub U, Orantes M, Braak H (2002) Phases of A betadeposition in the human brain and its relevance for the development of AD. Neurology 58(12):1791-1800. 
118. Lambert MP, Barlow AK, Chromy BA, et al. (1998) Diffusible, nonfibrillar ligands derived from Abeta1-42 are potent central nervous system neurotoxins. Proc Natl Acad Sci USA 95(11): 64486453.

119. Hayden EY, Teplow DB (2013) Amyloid beta-protein oligomers and Alzheimer's disease. Alzheimer's Res Ther 5(6): 60.

120. Viola KL, Klein WL (2015) Amyloid beta oligomers in Alzheimer's disease pathogenesis, treatment, and diagnosis. Acta neuropathol 129(2): 183-206.

121. Ferreira ST, Lourenco MV, Oliveira MM, De Felice FG (2015) Soluble amyloid-beta oligomers as synaptotoxins leading to cognitive impairment in Alzheimer's disease. Front Cell Neurosci 9:191.

122. Rothe K, Quandt D, Schubert K, Rossol M, Klingner M, et al. (2016) Latent Cytomegalovirus Infection in Rheumatoid Arthritis and Increased Frequencies of Cytolytic LIR-1+CD8+ T Cells. Arthritis Rheumatol 68(2):337-346.

123. Holmes C, Boche D, Wilkinson D, Yadegarfar G, Hopkins V, et al. (2008) Long-term effects of Abeta42 immunisation in Alzheimer's disease: follow-up of a randomised, placebo-controlled phase I trial. Lancet 372(9634): 216-223.

124. Gouras GK, Willen K, Faideau M (2014) The inside-out amyloid hypothesis and synapse pathology in Alzheimer's disease. Neurodegener Dis 13(2-3): 142-146.

125. Puzzo D, Gulisano W, Arancio O, Palmeri A (2015) The keystone of Alzheimer pathogenesis might be sought in Abeta physiology. Neuroscience 307:26-36.

126.Zheng L, Calvo-Garrido J, Hallbeck M, Hultenby K, Marcusson J, et al. (2013) Intracellular localization of amyloid-beta peptide in SH-SY5Y neuroblastoma cells. J Alzheimer's Dis 37(4):713-733.

127. Domert J, Rao SB, Agholme L, Brorsson AC, Marcusson J, et al. (2014) Spreading of amyloid-beta peptides via neuritic cell-to-cell transfer is dependent on insufficient cellular clearance. Neurobiol Dis 65:82-92.

128. Song HL, Shim S, Kim DH, Won SH, Joo S, et al. (2014) beta-Amyloid is transmitted via neuronal connections along axonal membranes. Ann Neurol 75(1): 88-97.

129. Ripoli C, Cocco S, Li Puma DD, et al. (2014) Intracellular accumulation of amyloid-beta (Abeta) protein plays a major role in Abeta-induced alterations of glutamatergic synaptic transmission and plasticity. J Neurosci 34(38):12893-12903.

130. Novotny R, Langer F, Mahler J, Skodras A, Vlachos A, et al. (2016) Conversion of Synthetic Abeta to In Vivo Active Seeds and Amyloid Plaque Formation in a Hippocampal Slice Culture Model. J Neurosci 36(18): 5084-5093.

131. Bouter Y, Dietrich K, Wittnam JL, Nasrollah Rezaei-Ghaleh, Thierry Pillot, et al. (2013) N-truncated amyloid beta (Abeta) 4-42 forms stable aggregates and induces acute and long-lasting behavioral deficits. Acta Neuropathol 126(2): 189-205.

132. Kane MD, Lipinski WJ, Callahan MJ (2000) Evidence for seeding of beta -amyloid by intracerebral infusion of Alzheimer brain extracts in beta -amyloid precursor protein-transgenic mice. J Neurosci 20(10): 3606-3611.

133. Meyer-Luehmann M, Coomaraswamy J, Bolmont T, Kaeser S, Schaefer C, et al. (2006) Exogenous induction of cerebral beta-amyloidogenesis is governed by agent and host. Science 313(5794): 1781-1784.

134. Eisele YS, Bolmont T, Heikenwalder M, Langer F, Jacobson LH, et al. (2009) Induction of cerebral beta-amyloidosis: intracerebral versus systemic Abeta inoculation. Proc Natl Acad Sci U S A 106(31): 1292612931.
135. Eisele YS, Obermuller U, Heilbronner G, Baumann F, Kaeser SA, et al. (2010) Peripherally applied Abeta-containing inoculates induce cerebral beta-amyloidosis. Science 330(6006): 980-982.

136. Morales R, Duran-Aniotz C, Castilla J, Estrada LD, Soto C (2012) De novo induction of amyloid-beta deposition in vivo. Molecular psychiatry 7(12): 1347-1353.

137. Hamaguchi T, Eisele YS, Varvel NH, Lamb BT, Walker LC, et al. (2012) The presence of Abeta seeds, and not age per se, is critical to the initiation of Abeta deposition in the brain. Acta Neuropathol 123(1): 31-37.

138. Heilbronner G, Eisele YS, Langer F, Kaeser SA, Novotny R, et al. (2013) Seeded strain-like transmission of beta-amyloid morphotypes in APP transgenic mice. ЕMBO reports 14(11): 1017-1022.

139. Stohr J, Condello C, Watts JC, Bloch L, Oehler A, et al. (2014) Distinct synthetic Abeta prion strains producing different amyloid deposits in bigenic mice. Proc Natl Acad Sci U S A 111(28):10329-10334.

140. Ye L, Hamaguchi T, Fritschi SK, Eisele YS, Obermüller U, et al. (2015) Progression of Seed-Induced Abeta Deposition within the Limbic Connectome. Brain pathol 25(6): 743-752.

141. DeGiorgio LA, Manuelidis L, Bernstein JJ (2002) Transient appearance of amyloid precursor protein plaques in the brain of thymectomized rats after human leptomeningeal cell grafts. Neuroscience lett 322(1): 62-66.

142. Baker HF, Ridley RM, Duchen LW, Crow TJ, Bruton CJ (1994) Induction of beta (A4)-amyloid in primates by injection of Alzheimer's disease brain homogenate. Comparison with transmission of spongiform encephalopathy. Mol Neurobiol 8(1): 25-39.

143. Lauren J, Gimbel DA, Nygaard HB, Gilbert JW, Strittmatter SM (2009) Cellular prion protein mediates impairment of synaptic plasticity by amyloid-beta oligomers. Nature 457(7233): 1128-1132.

144. Parkin ET, Watt NT, Hussain I, Eckman EA, Eckman CB, et al. (2007) Cellular prion protein regulates beta-secretase cleavage of the Alzheimer's amyloid precursor protein. Proc Natl Acad Sci U S A 104(26): 11062-11067.

145. Hainfellner JA, Wanschitz J, Jellinger K, Liberski PP, Gullotta F, et al. (1998) Coexistence of Alzheimer-type neuropathology in CreutzfeldtJakob disease. Acta Neuropathol 96(2): 116-122.

146. Oyanagi K, Makifuchi T, Ohtoh T, Chen KM, Gajdusek DC, et al. (1994) The neostriatum and nucleus accumbens in parkinsonism-dementia complex of Guam: a pathological comparison with Alzheimer's disease and progressive supranuclear palsy. Acta Neuropathol 88(2): 122-128.

147. Lee VM, Goedert M, Trojanowski JQ (2001) Neurodegenerative tauopathies. Annu Rev Neurosci 24: 1121-1159.

148. Kovacs GG (2015) Invited review: Neuropathology of tauopathies: principles and practice. Neuropathol Appl Neurobiol 41(1): 3-23.

149. Gaal C (1991) The problem of health insurance-based on the German model. Orvosi hetilap 132(11): 609.

150. Stancu IC, Vasconcelos B, Terwel D, Dewachter I (2014) Models of beta-amyloid induced Tau-pathology: the long and "folded" road to understand the mechanism. Mol Neurodegener 9:51.

151. Clavaguera F, Bolmont T, Crowther RA, Dorothee Abramowski, Stephan Frank et al. (2009) Transmission and spreading of tauopathy in transgenic mouse brain. Nat cell bio 11(7): 909-913.

152. Guo JL, Lee VM (2013) Neurofibrillary tangle-like tau pathology induced by synthetic tau fibrils in primary neurons over-expressing mutant tau. FEBS lett 587(6): 717-723. 
153. Iba M, Guo JL, McBride JD, Zhang B, Trojanowski JQ et al. (2013) Synthetic tau fibrils mediate transmission of neurofibrillary tangles in a transgenic mouse model of Alzheimer's-like tauopathy. J Neurosci 33(3): 1024-1037.

154. Clavaguera F, Akatsu H, Fraser G, R. Anthony Crowther, Stephan Frank et al. (2013) Brain homogenates from human tauopathies induce tau inclusions in mouse brain. Proc Natl Acad Sci U S A 110(23): 95359540.

155. Sanders DW, Kaufman SK, DeVos SL, Sharma AM, Mirbaha H, et al. (2014) Distinct tau prion strains propagate in cells and mice and define different tauopathies. Neuron 82(6): 1271-1288.

156. Peeraer E, Bottelbergs A, Van Kolen K, Stancu IC, Vasconcelos B, et al. (2015) Intracerebral injection of preformed synthetic tau fibrils initiates widespread tauopathy and neuronal loss in the brains of tau transgenic mice. Neurobiol Dis 73: 83-95.

157. Boluda S, Iba M, Zhang B, Raible KM, Lee VM, et al. (2015) Differential induction and spread of tau pathology in young PS19 tau transgenic mice following intracerebral injections of pathological tau from Alzheimer's disease or corticobasal degeneration brains. Acta Neuropathol 129(2): 221-237.

158. Stancu IC, Vasconcelos B, Ris L, Wang P, Villers A, et al. (2015) Templated misfolding of Tau by prion-like seeding along neuronal connections impairs neuronal network function and associated behavioral outcomes in Tau transgenic mice. Acta Neuropathol 129(6): 875-894.

159. Takahashi M, Miyata H, Kametani F, Nonaka T, Akiyama H, et al. (2015) Extracellular association of APP and tau fibrils induces intracellular aggregate formation of tau. Acta Neuropathol 129(6): 895-907.

160. Asai H, Ikezu S, Tsunoda S, Medalla M, Luebke J, et al. (2015) Depletion of microglia and inhibition of exosome synthesis halt tau propagation. Nat Neurosci 18(11): 1584-1593.

161. Vasconcelos B, Stancu IC, Buist A, Bird M, Wang P, et al. (2016) Heterotypic seeding of Tau fibrillization by pre-aggregated Abeta provides potent seeds for prion-like seeding and propagation of Taupathology in vivo. Acta Neuropathol 131(4): 549-569.

162. Xu Y, Martini-Stoica H, Zheng H (2016) A seeding based cellular assay of tauopathy. Molecular neurodegeneration 11: 32.

163. Weisman D, McKeith I (2007) Dementia with Lewy bodies. Semin Neurol 27(1): 42-47.

164. Seidel K, Mahlke J, Siswanto S, Krüger R, Heinsen H, et al. (2015) The brainstem pathologies of Parkinson's disease and dementia with Lewy bodies. Brain pathol 25(2): 121-135.

165. Gomperts SN (2016) Lewy Body Dementias: Dementia With Lewy Bodies and Parkinson Disease Dementia. Continuum 22(2 Dementia): 435-463.

166. Graham JG, Oppenheimer DR (1969) Orthostatic hypotension and nicotine sensitivity in a case of multiple system atrophy. J Neurol Neurosurg Psychiatry 32(1): 28-34.

167. Ahmed Z, Asi YT, Sailer A, Lees AJ, Houlden H, et al. (2012) The neuropathology, pathophysiology and genetics of multiple system atrophy. Neuropathol Appl Neurobiol 38(1): 4-24.

168. Ciolli L, Krismer F, Nicoletti F, Wenning GK (2014) An update on the cerebellar subtype of multiple system atrophy. Cerebellum Ataxias $1: 14$.

169. McCann H, Stevens CH, Cartwright H, Halliday GM (2014) alphaSynucleinopathy phenotypes. Parkinsonism Relat Disord 20(Suppl 1): S62-67.
170. de Lau LM, Breteler MM (2006) Epidemiology of Parkinson's disease. Lancet Neurol 5(6): 525-535.

171. Hirsch L, Jette N, Frolkis A, Steeves T, Pringsheim T (2016) The Incidence of Parkinson's Disease: A Systematic Review and MetaAnalysis. Neuroepidemiology 46(4): 292-300.

172. Noyce AJ, Lees AJ, Schrag AE (2016) The prediagnostic phase of Parkinson's disease. J Neurol Neurosurg Psychiatry.

173. Launay PS, Reboussin E, Liang H, Kessal K, Godefroy D, et al. (2016) Ocular inflammation induces trigeminal pain, peripheral and central neuroinflammatory mechanisms. Neurobiol Dis 88: 16-28.

174. Braak H, Ghebremedhin E, Rub U, Bratzke H, Del Tredici K (2004) Stages in the development of Parkinson's disease-related pathology. Cell Tissue Res 318(1): 121-134.

175. Kordower JH, Chu Y, Hauser RA, Freeman TB, Olanow CW (2008) Lewy body-like pathology in long-term embryonic nigral transplants in Parkinson's disease. Nat Med 14(5): 504-506.

176. Li JY, Englund E, Holton JL, et al. Lewy bodies in grafted neurons in subjects with Parkinson's disease suggest host-to-graft disease propagation. Nat Med May 2008;14(5): 501-503.

177. Danzer KM, Krebs SK, Wolff M, Birk G, Hengerer B (2009) Seeding induced by alpha-synuclein oligomers provides evidence for spreading of alpha-synuclein pathology. J Neurochem 111(1): 192203.

178. Hansen C, Angot E, Bergstrom AL, Steiner JA, Pieri L, et al. (2011) alphaSynuclein propagates from mouse brain to grafted dopaminergic neurons and seeds aggregation in cultured human cells. J Clin Invest 121(2): 715-725.

179. Guo JL, Covell DJ, Daniels JP, Iba M, Stieber A, et al. (2013) Distinct alpha-synuclein strains differentially promote tau inclusions in neurons. Cell 154(1): 103-117.

180.Aulic S, Le TT, Moda F, Loredana Casalis, Stefano Gustincich, et al (2014) Defined alpha-synuclein prion-like molecular assemblies spreading in cell culture. BMC neuroscience 15: 69.

181. Reyes JF, Olsson TT, Lamberts JT, Devine MJ, Kunath T, et al. (2015) A cell culture model for monitoring alpha-synuclein cell-to-cell transfer Neurobiol Dis 77: 266-275.

182. Woerman AL, Stohr J, Aoyagi A, Rampersaud R1, Krejciova Z, et al (2015) Propagation of prions causing synucleinopathies in cultured cells. Proc Natl Acad Sci U S A 112(35): E4949-4958.

183. Prusiner SB, Woerman AL, Mordes DA, Joel C watts, Ryan Rapersuad, et al. (2015) Evidence for alpha-synuclein prions causing multiple system atrophy in humans with parkinsonism. Proc Natl Acad Sci U S A 112(38): E5308-5317.

184. Bae EJ, Lee HJ, Lee SJ (2016) Cell Models to Study Cell-to-Cell Transmission of alpha-Synuclein. Methods Mol Biol 1345: 291-298.

185. Pinotsi D, Michel CH, Buell AK, Laine RF, Mahou P, et al. (2016) Nanoscopic insights into seeding mechanisms and toxicity of alphasynuclein species in neurons. Proc Natl Acad Sci U S A 113(14): 38153819.

186. Desplats P, Lee HJ, Bae EJ, et al. Inclusion formation and neuronal cell death through neuron-to-neuron transmission of alpha-synuclein. Proc Natl Acad Sci U S A Aug 4 2009;106(31):13010-13015.

187. Mougenot AL, Nicot S, Bencsik A, Morignat E, Verchère J, et al. (2012) Prion-like acceleration of a synucleinopathy in a transgenic mouse model. Neurobiology of aging 33(9): 2225-2228.

188. Luk KC, Kehm VM, Zhang B, O’Brien P, Trojanowski JQ, et al. (2012) Intracerebral inoculation of pathological alpha-synuclein initiates 
a rapidly progressive neurodegenerative alpha-synucleinopathy in mice. J Exp Med 209(5): 975-986.

189. Luk KC, Kehm V, Carroll J, Zhang B, O Brien P, et al. (2012) Pathological alpha-synuclein transmission initiates Parkinson-like neurodegeneration in nontransgenic mice. Science 338(6109): 949953.

190. Masuda-Suzukake M, Nonaka T, Hosokawa M, et al. (2013) Prion-like spreading of pathological alpha-synuclein in brain. Brain 136(Pt 4): 1128-1138.

191. Watts JC, Giles K, Oehler A, Lefkos Middleton, ${ }^{\text {David T Dexter }}$, et al. (2013) Transmission of multiple system atrophy prions to transgenic mice. Proc Natl Acad Sci U S A 110(48):19555-19560.

192. Betemps D, Verchere J, Brot S, Morignat E, Bousset L, et al. (2014) Alpha-synuclein spreading in M83 mice brain revealed by detection of pathological alpha-synuclein by enhanced ELISA. Acta Neuropathol Commun 2: 29.

193. Ulusoy A, Musgrove RE, Rusconi R, Klinkenberg M, Helwig M, et al. (2015) Neuron-to-neuron alpha-synuclein propagation in vivo is independent of neuronal injury. Acta Neuropathol Commun 3:13.

194. Paumier KL, Luk KC, Manfredsson FP, Kanaan NM, Lipton JW, et al. (2015) Intrastriatal injection of pre-formed mouse alpha-synuclein fibrils into rats triggers alpha-synuclein pathology and bilateral nigrostriatal degeneration. Neurobiol Dis 82: 185-199.

195. Jones DR, Delenclos M, Baine AT, DeTure M, Murray ME, et al. (2015) Transmission of Soluble and Insoluble alpha-Synuclein to Mice. J Neuropathol Exp Neurol 74(12): 1158-1169.

196. Bernis ME, Babila JT, Breid S, Wusten KA, Wullner U, et al. (2015) Prion-like propagation of human brain-derived alpha-synuclein in transgenic mice expressing human wild-type alpha-synuclein. Acta Neuropathol Commun 3:75.

197. Fares MB, Maco B, Oueslati A, Rockenstein E, Ninkina N, et al. (2016) Induction of de novo alpha-synuclein fibrillization in a neuronal model for Parkinson's disease. Proc Natl Acad Sci U S A 113(7): E912921.

198.Zhang J, Tan D, DeRose EF, Perera L, Dominski Z, et al. (2014) Molecular mechanisms for the regulation of histone mRNA stem-loopbinding protein by phosphorylation. Proc Natl Acad Sci U S A 111(29): E2937-2946.

199. Volpicelli-Daley LA, Luk KC, Patel TP, Tanik SA, Riddle DM, et al. (2011) Exogenous alpha-synuclein fibrils induce Lewy body pathology leading to synaptic dysfunction and neuron death. Neuron 72(1): $57-$ 71.

200. Steiner JA, Angot E, Brundin P (2011) A deadly spread: cellular mechanisms of alpha-synuclein transfer. Cell Death Differ Sep 18(9): 1425-1433.

201. Danzer KM, Haasen D, Karow AR, Moussaud S, Habeck M, et al. (2007) Different species of alpha-synuclein oligomers induce calcium influx and seeding. J Neurosci 27(34): 9220-9232.

202. Kordower JH, Dodiya HB, Kordower AM, Terpstra B, Paumier K, et al. (2011) Transfer of host-derived alpha synuclein to grafted dopaminergic neurons in rat. Neurobiol Dis 43(3): 552-557.

203. Rey NL, Petit GH, Bousset L, Melki R, Brundin P (2013) Transfer of human alpha-synuclein from the olfactory bulb to interconnected brain regions in mice. Acta Neuropathol 126(4): 555-573.

204. Pieri L, Madiona K, Melki R (2016) Structural and functional properties of prefibrillar alpha-synuclein oligomers. Scientific reports 6: 24526.

205. Iljina M, Garcia GA, Horrocks MH, Laura Tosatto,Minee L Choi, et al. (2016) Kinetic model of the aggregation of alpha-synuclein provides insights into prion-like spreading. Proc Natl Acad Sci U S A 113(9): E1206- E1215.

206. Giasson BI, Forman MS, Higuchi M, Golbe LI, Graves CL, et al. (2003) Initiation and synergistic fibrillization of tau and alpha-synuclein. Science 300(5619): 636-640.

207. Ciaccioli G, Martins A, Rodrigues C, Vieira H, Calado P (2013) A powerful yeast model to investigate the synergistic interaction of alpha-synuclein and tau in neurodegeneration. PloS one 8(2): e55848.

208. Badiola N, de Oliveira RM, Herrera F, Guardia-Laguarta C, Gonçalves SA, et al. (2011) Tau enhances alpha-synuclein aggregation and toxicity in cellular models of synucleinopathy. PloS one 6(10): e26609.

209. Fritschi SK, Cintron A, Ye L, Mahler J, Bühler A, et al. (2014) Abeta seeds resist inactivation by formaldehyde. Acta Neuropathol 128(4): 477-484.

210. Thomzig A, Wagenfuhr K, Daus ML, Joncic M, Schulz-Schaeffer WJ, et al. (2014) Decontamination of medical devices from pathological amyloid-beta-, tau- and alpha-synuclein aggregates. Acta Neuropathol Commun 2: 151

211. Chapuis J, Moudjou M, Reine F, Herzog L, Jaumain E, et al. (2016) Emergence of two prion subtypes in ovine PrP transgenic mice infected with human MM2-cortical Creutzfeldt-Jakob disease prions. Acta Neuropathol Commun 4: 10.

\section{Your next submission with Juniper Publishers} will reach you the below assets

- Quality Editorial service

- Swift Peer Review

- Reprints availability

- E-prints Service

- Manuscript Podcast for convenient understanding

- Global attainment for your research

- Manuscript accessibility in different formats

( Pdf, E-pub, Full Text, Audio)

- Unceasing customer service

Track the below URL for one-step submission https://juniperpublishers.com/online-submission.php 